\title{
African Digital Diasporas: Technologies, Tactics, and Trends
}

\section{Introduction}

\author{
Victoria Bernal \\ University of California, Irvine, CA, USA \\ vbernal@uci.edu
}

Africans and Diaspora

Diasporas have a long history. The essence of diaspora is some form of displacement coupled with relations of belonging and identification that link members of a diaspora to each other and to a shared origin (Braziel and Mannur 2007). In the case of African diasporas, their long history stems largely from the European enslavement and transport of Africans from the continent to the Americas. The term 'African diaspora', therefore, has generally been understood to refer to the well-established populations of African descent in the Western hemisphere whose ties to particular places, communities, or institutions on the continent had been severed by force and subsequently lost. An unintended effect of this construction of African diaspora was that it rendered invisible Africans who left Africa more recently and established themselves on other continents. As Kamari Clarke (2010: 48) observes this has been changing as "scholars have extended the terrain of African American and Africana studies by creating a widening field of engagement that makes the Africa in 'African American' present". As Clarke's formulation suggests, longstanding notions of African diaspora also centered on American racialised experiences.

These views have been shifting as scholars and publics increasingly recognise the diversity and extent of African diasporas around the globe (Pitts 2019; Alves 2018; Winders 2007; Gilroy 1993). The meanings and implications of the concept of 'African diaspora', thus, are complex, contested, and evolving (Kamel 2011; Rahier et al 2010; Zeleza 2010; Okpewho and Nzegwu 2009). Over the past decade, however, the so-called 'migrant crisis' in Europe and the media circulation of images showing Africans at risk or drowned in the Mediterranean, languishing in makeshift camps at Calais, and other scenes of 
desperation have brought new African diasporas into greater visibility on the global stage (Rinelli 2015).

New African diasporas share experiences of anti-black racism and discrimination with established African heritage diasporas (Sawyer 2008; CopelandCarson 2004). Newer arrivals, nonetheless, also confront distinctive conditions. Many face challenges because they do not have legal citizenship status in the host countries where they live, and they encounter restrictions on their international mobility (Collyer 2006; also see Dubinsky this issue). Members of these African diasporas often face struggles arising from linguistic, religious, and/or cultural differences from the host societies in which they are living (Besteman 2016; Fumanti and Werbner 2010; Abusharaf 2002). The lives of new African diasporas are also profoundly affected by the fact that they have strong ties, and often responsibilities to families, communities, and/or social and political movements in the African countries they left (Assal 2004; Bernal 2004; Carter 1997; see also Turner and Berckmoes this issue). African diasporas are diverse and dynamic, particularly as people continue to migrate from the continent and settle abroad, and as new generations are born in diaspora (Falola 2014).

Digital media have transformed the experiences and practices of African diasporas (Hafkin 2015; Bernal 2014). Africans on the continent and in the diaspora have been quick to embrace digital media. This may be because the forms of sociality fostered by digital connectivity are so conducive to long-standing African values and practices of sociality. Guyer's (1993:243) influential analysis, summed up in the concept of "wealth in people", notably points to this value system as extending beyond kinship relations, calling it a "non-genealogical, accumulative logic". While her formulation may be overly materialist, it continues to resonate among scholars who see Africans placing a high value on personal connections, and actively working to develop and maintain extensive networks of social ties. As Grosz-Ngate (2014: 80) observes, non-kin associations of various kinds "offer their members sociability, moral support, and an opportunity to expand personal networks". Considering social media, the phenomena of 'Facebook friends' for example, that signals outer circles of social relationships which are sustained largely through phatic communication, but could possibly be mobilised under some circumstances, seems novel in relation to conventional notions of friendship in the Global North. But such relationships have precedents in the extensive 'on the ground' social networks that have long been a hallmark of African sociality.

In considering the sociality of African diasporas, Everett's depiction of enslaved Africans forging new communities is interesting for how we might read it in relation to the contemporary digitally mediated sociality of diasporas today: 
Severed from the familiar terrain of their homelands and dispatched to the overcrowded bowels of slave vessels, the abducted Africans forged out of necessity a virtual community of intercultural kinship structures and new languages in which to express them.

EVERETT 2OO9: 2

Her description of people separated from their homelands, who respond creatively by constructing new forms of diasporic identity and 'virtual community' calls to my mind, for example, the Eritreans from different ethnic and religious backgrounds dispersed across numerous countries who came together on the first Eritrean diaspora website, Dehai.org.

While notions of African diaspora have expanded to recognise transnational migration from Africa in the 2oth and 21st centuries, ideas about digital media and social life have also evolved.

Early studies of digitally mediated sociality often focused on online communities and cybercultures, viewing the internet in terms of virtuality (Ess 2001; Bell and Kennedy 2000). However, as digital media and devices, particularly the smart phone, became ever more mobile and pervasive the distinction between the online and offline dimensions of communication and interaction has faded. People no longer experience going online as entering a separate realm, rather connectivity is now entwined with their lives as part of carrying out everyday activities (Boyd 2012). The concept of African digital diasporas as used in this collection of essays, thus, does not refer to online communities specifically, but reflects the integration of digital connectivity into people's lives.

Early internet studies often celebrated digital media as liberating and empowering for marginalised groups and ordinary people. The core problem was then understood in terms of unequal access, 'the digital divide' (Norris 2001). More complex critical analyses raised questions about the nature of digital empowerment and whether and how online communication could bring about political change (Papacharissi 2015; Zayani 2015; Gajjala 2008). The past decade, in particular, has yielded critical perspectives focused on how corporations and states use digital capabilities to extend and enhance centralised power (Zuboff 2019; Langlois et al 2015 also see Ibara-Manuel this issue).

Research on digital diasporas brings together complex intersections of technology, culture, political economy, and agency that are diverse and evolving. 
As Candidatu et al. (2019: 34) explain, digital diasporas are "mutually constituted here and there, through bodies and data, across borders and networks, online and offline, by users and platforms, through material, symbolic, and emotional practices that are all reflective of intersecting power relations". The understanding of digital diasporas, therefore, must be attentive to "the changing structural conditions of migrants and the proliferation of forms of media" (Andersson 2019: 142). It is also important to consider digital media in the context of North/South relations.

Tech developers in Silicon Valley have dominated the industry, designing with affluent consumers of the Global North in mind. Indeed Africans have been called 'invisible users' because their circumstances, habits, and desires have not figured into the thinking of digital developers (Burrell 2012). As Royston, (this issue) notes, "diaspora-homeland connections for Africans as a whole are not well-mediated by the large engines of this connection, namely global telecom firms". Yet Africans on the continent and in diaspora have not only used digital media, they have innovated and adapted it for their own diverse purposes (Pype 2016; Archambault 2013; Rutten and Mwangi 2012). Digital media offer African diasporas an immediacy of connection to people and institutions in the homeland as well as to communities and compatriots in diaspora. African diasporas use the internet to act and communicate across geographic and political borders. Connectivity may blur the boundaries between those inside and those outside the homeland or home community. Using digital media African diasporas have created new public spheres, forms of protest, social groupings, and spaces of imagination.

\section{The Articles}

Each of the articles collected here brings into focus distinct facets of the relationship between African diasporas and digital media. The authors present original data and analyses that elucidate a particular case while offering insights that help chart future directions for research. They employ a range of methodologies for understanding digital media and African diasporas. All of them situate their research in reference to current scholarship and theorising, while taking care to contextualise and historicise their observations. The articles raise questions about Technologies, digital capabilities, infrastructures, and platforms; about Tactics, drawing attention to the agency of Africans in managing digital media and their social lives; and together they point to Trends, the continued evolution of digital capacities and the expansion of the digital into ever more experiences and domains of life, the developing theories of 
diaspora and digital media, and the on-going struggles of Africans for various forms of freedom and agency in our global era.

Reginold Royston's essay asks us to attend to the materialities of digital media and the significance of technological infrastructures which offer constraints and opportunities for the creativity of Ghanaians. Royston brings into focus the material disjunctions of digital networks that produce asymmetries. He shows how "The assembling and administration of physical networking tools which enable transnational social networks (mobiles, routers, cell towers, fiber optic cables, etc.), and the social constraints in which they are situated, are configured by and also configure Ghanaians as they negotiate these global infrastructures". Royston identifies what he calls 'tactics of innovation', charting how diaspora Ghanaians find workarounds to enable connectivity in the face of material constraints. His analysis reveals the continued significance of geographies for digital diasporas, and the ways technological infrastructures become boundary-marking devices. He demonstrates the importance of research attending to the physical construction of networks, rather than simply to the content of communications, while also showing how the agency of the Ghanaian digital diaspora brings about new configurations of the technological and the social.

While much scholarship has focused on the frictionless and inexpensive nature of digital communications, Turner and Berckmoes reveal how the immediacy of connection can also pose a burden on diasporas. Their research counters "the impression that diasporic engagement simply grows with the growth of information flows due to the spread of ICT and social media across the continent". They draw attention to the tactics of Burundians in diaspora who are not simply passive consumers or recipients of connectivity and the flows of information afforded by digital media, but develop strategies to manage their engagement and filter information flows in order to temper the emotional impact on their lives. At the same time, Turner and Berckmoes observe that in the context of on-going political conflict in Burundi, people depend on unofficial sources such as WhatsApp groups for information on which to make strategic life-and-death decisions about whether Burundi is a safe place for their relatives to remain or for themselves to return to. In highlighting the emotional work involved in managing connectivity in the shifting context of homeland conflict, Turner and Berckmoes bring affect to the center of thinking about African digital diasporas. They call on researchers to "both investigate how the flows develop over time and map the mechanisms that influence it".

Yemisi Akinbobola puts women at the center of her analysis. Her essay explores scholarly debates about African feminism while examining a Twitter hashtag started by women in Nigeria that drew participants of both genders 
from the diaspora as well as from inside the country. Akinbobola posits that "[if] feminism is un-African, we must ask what does being 'African' mean and who determines this? Why should the state of being African remain a fixed, never developing/modifying state?" She notes that while gatekeepers in mainstream media have marginalised black women, digital media are more accessible. In this regard, women taking to Twitter can be seen as a tactic to enter the public sphere. By starting \#BeingFemaleinNigeria, women created a space for other women to tell their stories, and opened a conversation about lived gender experiences among diverse participants. Using discourse analysis Akinbobola identifies the main themes emerging from women's use of social media to expose gender inequality. She finds that issues of marriage and divorce are the most salient for women, suggesting that patriarchal family relationships remain central to lives of Nigerian women whether at home or in diaspora. Akinbobola argues that this Twitter hashtag constituted a form of transnational and transcultural activism because it set off exchanges among Nigerian women and men inside and outside the country around the state of Nigerian gender relations.

Itamar Dubinsky takes us to the contemporary, precarious case of African diasporas who are refugees. While some observers have viewed smart phones and connectivity as luxuries incompatible with refugee status, Dubinsky shows how vital these are for Eritrean refugees in Israel. They use a range of digital affordances and platforms including diaspora websites, PalTalk, and Facebook to navigate their difficult circumstances, to help fellow migrants, and to agitate for change in their homeland. Discussing refugees' cyberactivism, Dubinsky sees digital media as crucial because "online spheres provide spaces for diasporic politics that cannot exist in 'offline' spheres" where Eritreans face repression. Organising online also makes it possible for them to translate criticism into action by staging demonstrations in Israel. Nonetheless, Dubinsky quotes his interlocutors expressing doubts about whether cyberactivism has an impact. He notes that further research is required to reveal the full political potential of digital diasporas.

Irene Fubara-Manuel addresses the rising use of biometrics in the context of anti-black racism and anti-immigrant sentiments in the United Kingdom. Her essay makes clear that African diasporas inhabit a digital world whether they choose to or not. "Placed in networked databases shared amongst international organisations, airports and countries, biometric data links the body to a digital identity, ensuring that no matter where they are located migrants are always bound in digital captivity to the border". She argues, moreover, that African migrants are disproportionately targeted by hegemonic systems of codification and capture made possible by digital technologies. The growing use of biomet- 
rics, surveillance cameras, and the collection and circulation of diverse forms of digital data operate as infrastructures creating the conditions of people's lives. From this critical perspective, digital empowerment for African diasporas can only be achieved when technologies of capture are disrupted and fail. Fubara-Manuel calls for resistance to this system, analysing two artistic works of resistance by 'black digital practitioners'. With the concept of 'computational creole', she envisions decolonial technological development that invites experimentations and explorations that centre freedom from digital captivity or surveillance.

Stan Squirewell's art and the accompanying essay co-authored with Jack Boulton confronts us with histories of racialisation, the complexities of black identity, and on-going questions of power, oppression and struggle. Squirewell's compositions foreground strong black bodies, Kente cloth, and other symbols of Africa, combining them with other elements and symbols in ways that construct surprising and sometimes shocking hybrids. In describing his work Squirewell says,

I am examining the relativity of global indigenous geometric patterns, specifically West African Kente schema, as a possible progenitor of modern digital cultures. I see overwhelming similarities in basic constructions and designs of computer processing chips and video games to the geometrical weave of the cloth. The vividly bold colors, precise hard lines, sequential rhythms and movements attest to the high intellectual capacity of those whom were called 'Primitive'.

His title for this series of works, 'Algorithmic-Carbon' suggests digital processes and endless permutations that continue to yield possibilities for re-imagining blackness in the world and for recomposing the world in the process.

In sum, these essays and art work shed light on the complexities and contradictions of African diasporas' diverse social and political contexts and their engagements and entanglements with digital media. They reveal the ingenuity and adaptability of African diasporas. These studies, furthermore, provide insights and provoke questions about digital capacities and connectivity that are relevant to wider publics and scholars interested in understanding the ongoing transformations in our social worlds through digital media. 


\section{Acknowledgements}

I am grateful to Karel Arnaut and the editorial board for the opportunity to edit this special issue, and to the anonymous reviewers and board members who commented on multiple drafts of the articles. I thank Jack Boulton for his heroic work behind the scenes, communicating with authors and copyediting the essays. I especially thank KU Leuven for a Senior Research Fellowship 2018-2019 during which much of the work for this special issue was completed.

\section{References}

Abusharaf, Rogaia 2002 Wanderings: Sudanese Migrants and Exiles in North America. Ithaca: Cornell University Press.

Alves, Jaime Amparo 2018 The Anti-Black City: Police Terror and Black Urban Life in Brazil. Minneapolis: University of Minnesota Press.

Andersson, Kerstin 2019 'Digtial Diasporas: An Overview of the Research Areas of Migration and New Media Through a Narrative Literature Review'. Human Technology $15(2)$ : 142-180.

Archambault, Julie 2013 'Cruising through uncertainty: Cell phones and the politics of display and disguise in Inhambane, Mozambique'. American Ethnologist 40 (1): 88101.

Assal, Munzoul 2004 Sticky Labels or Rich Ambiguities: Diaspora and Challenges of Homemaking for Somalis and Sudanese in Norway. Bergen: BRIC.

Bell, David and Barbara Kennedy, eds. 2000 The Cybercultures Reader. New York and London: Routledge.

Bernal, Victoria 2004 'Eritrea Goes Global: Reflections on Nationalism in a Transnational Era.' Cultural Anthropology 19 (1): 1-25.

Bernal, Victoria 2014 Nation as Network:Diaspora, Cyberspace, and Citizenship. Chicago: University of Chicago Press.

Besteman, Catherine 2016 Making Refuge: Somali Bantu Refugees and Lewiston, Maine. Durham: Duke University Press.

Boyd, Danah 2012 'Participating in the Always-On Lifestyle' In The Social Media Reader, edited by Michael Mandiberg. New York: New York University Press. Pp. 71-76.

Braziel, Jana and Anita Mannur, eds. Theorizing Diaspora. Oxford: Blackwell Publishing. Burrell, Jenna 2012 Invisible Users: Youth in the Internet Cafes of Urban Ghana. Cambridge: MIT Press.

Candidatu, Laura, Koen Leurs, and Sandra Ponzanesi 2019 'Digital Diasporas: Beyond the Buzzword Toward a Relational Understanding of Mobility and Connectivity' 
In The Handbook of Diasporas, Media, and Culture, edited by Jessica Retis Roza Tsagarousianou. Hoboken: Wiley Blackwell. Pp. 31-47.

Carter, Donald 1997 States of Grace: Senegalese in Italy and the New European Immigration. Minneapolis: University of Minnesota Press.

Clarke, Kamari 2010 'New Spheres of Transnational Formations: Mobilizations of Humanitarian Diasporas'. Transforming Anthropology 18 (1): 48-65.

Collyer, Michael 2006 'Undocumented Sub-Saharan African Migrants in Morocco'. In Mediterranean Transit Migration, edited by Ninna Nyberg Sorenson. Copenhagen: Danish Institute for International Studies. Pp. 129-146.

Copeland-Carson, Jacqueline 2004 Creating Africa in America: Translocal Identity in an Emerging World City. Philadelphia: University of Pennsylvania Press.

Ess, Charles, editor 2001 Culture, Technology, Communication: Towards and Intercultural Global Village. Albany: sunY Press.

Everett, Anna 2009 Digital Diaspora: A Race for Cyberspace. Albany: sunY Press.

Falola, Toyin 2014 The African Diaspora: Slavery, Modernity, and Globalization.

Rochester: University of Rochester Press.

Fumanti, Mattia and Pnina Werbner 2010 'The Moral Economy of the African Diaspora: Citizenship, Networking and Permeable Ethnicity'. Africa Diaspora 3: 2-11.

Gajjala, Radhika 2008 'Conclusion: Moving On, Re-Mixing it Up: Web 2.0, Offline/ Online Intersections, Globalization through NGos, Machinima, Mash-ups .... In South Asian Technospaces, edited by Radhika Gajjala and Venkataramana Gajjala. New York: Peter Lang. Pp. 265-274.

Gilroy, Paul 1993 The Black Atlantic: Modernity and Double Consciousness. Cambridge: Harvard University Press.

Grosz-Ngate, Maria 2014 'Social Relations: Family, Kinship, and Community' In Africa, edited by Maria Grosz-Ngate, John Hanson, and Patrick O'Meara. Bloomington: Indiana University Press. Pp. 56-82.

Guyer, Jane 1993 'Wealth in People and Self-Realization in Equatorial Africa'. Man 28 (2): $243^{-265}$.

Hafkin, Nancy 2015 “"Whatsupoc” on the Net: The Role of Information and Communication Technology in the Shaping of Transnational Ethiopian Identity'. In Creating the Ethiopian Diaspora, edited by Kay Shelemany and Steven Kaplan. Los Angeles: Tshai Publishers. Pp. 29-54.

Kamel, Seraphina. 2011 'Diaspora as the "Sixth Region of Africa": An Assessment of the African Union Initiative 2002-2010', Diaspora Studies 4 (1).

Langlois, Ganaele, Joanna Redden, and Greg Elmer, eds. 2015 Compromised Data: From Social Media to Big Data. New York: Bloomsbury.

Norris, Pippa 2001 The Digital Divide: Civic Engagement, Information Poverty, and the Internet Worldwide. Cambridge: Cambridge University Press.

Okpewho, Isidore and Nkiru Nzegwu, eds. The New African Diaspora. Bloomington: Indiana University Press. 
Papacharissi, Zizi 2015 Affective Publics: Sentiment, Technology, and Politics. Oxford: Oxford University Press.

Pitts, Johny 2019 Afropean: Notes From Black Europe. London: Allen Lane.

Pype, Katrien 2016. '(Not) Talking like a Motorola. Practices of Masking and Unmasking in Kinshasa's Mobile Phone Culture'. Journal of the Royal Anthropological Institute 22(3):633-653.

Rahier, Jean 2010 'The Diversity of Diasporic Subjectivities: Different and Separate Ontologies?' A Response to Kamari Clarke's 'New Spheres of Transnational Formations: Mobilizations of Humanitarian Diasporas'. Transforming Anthropology 18(1): $66-69$.

Rahier, Jean, Percy Hintzen and Felipe Smith, eds. 2010 Global Circuits of Blackness: Interrogating the African Diaspora. Champaign: University of Illinois Press.

Rinelli, Lorenzo 2015 African Migrants and Europe: Managing the Ultimate Frontier. New York: Routledge.

Rutten, Marcel and Moses Mwangi 2012 'Mobile cash for nomadic livestock keepers: The impact of the mobile phone innovation (M-Pesa) on Maasai pastoralists in Kenya'. In Transforming Innovations in Africa: Explorative Studies on Appropriation in African Societies, edited by Jan-Bart Gewald, André Leliveld, and Iva Pesa. Leiden: Brill. Pp. 79-101.

Sawyer, Lena 2008 'Routings: "Race”, African Diasporas, and Swedish Belonging'. Transforming Anthropology 11(1):13-35.

Winders, James 2007 Paris Africain: Rhythms of the African Diaspora. London: Palgrave MacMillan.

Zayani, Mohamed 2015 Networked Publics and Digital Contention: the Politics of Everyday Life in Tunisia. Oxford: Oxford University Press.

Zeleza, Paul 2010. 'African Diasporas: Toward a Global History'. African Studies Review, 53(1):1-19.

Zuboff, Shoshana 2019 The Age of Surveillance Capitalism. The Fight for a Human Future at the New Frontier of Power. New York: Public Affairs. 